\title{
Serum Calprotectin and Iron Metabolism Biomarker Levels in Behçet's Disease
}

\author{
Behçet Hastalığında Serum Kalprotektin ve Demir Metabolizması Biyobelirteç Düzeyleri \\ (D) Ahmet Karadağ, (1) Halef Okan Doğan* \\ Sivas Cumhuriyet University Faculty of Medicine, Department of Physical Medicine and Rehabilitation, Sivas, Turkey \\ * Sivas Cumhuriyet University Faculty of Medicine, Department of Biochemistry, Sivas, Turkey
}

\section{Abstract}

Objective: This study aimed to investigate the serum levels of calprotectin, hepcidin, iron, and ferritin in Behçet's disease (BD).

Materials and Methods: This study included 40 patients with BD who met the diagnostic criteria of the BD International Study Group (1990) and 40 healthy control participants. Serum high-sensitive C-reactive protein (hsCRP), hepcidin, calprotectin, ferritin, iron, and unsaturated iron-binding capacity (UIBC) levels were determined in all study participants.

Results: Statistically significant difference was found between the groups in respect of calprotectin ( $p<0.05), \mathrm{UIBC}(\mathrm{p}<0.05), \mathrm{hsCRP}(\mathrm{p}<0.05)$, and hemoglobin $(p<0.05)$ levels. No statistically significant differences were determined between the patients and the controls in terms of hepcidin, iron, and ferritin levels. Cut-off value of $212.3 \mathrm{pg} / \mathrm{mL}$ for calprotectin was determined to identify patients with BD having a sensitivity and specificity of $100 \%$ and $90 \%$, respectively.

Conclusion: Serum calprotectin may be a useful biomarker in the evaluation of inflammatory status and BD diagnosis. Total iron-binding capacity and hemoglobin may be more useful in evaluating iron deficiency anemia in patients with BD.

Keywords: Behçet's disease, calprotectin, hepcidin, iron, ferritin

\section{Öz}

Amaç: Bu çalışmanın amacı Behçet hastalığında $(\mathrm{BH})$ serum kalprotektin, hepsidin, demir ve ferritin düzeylerini araştırmaktır.

Gereç ve Yöntem: Çalışmaya Uluslararası BH Çalışma Grubu tanı kriterlerine (1990) göre 40 Behçet hastası ve 40 sağlıklı birey dahil edildi. Çalışmaya katılan tüm bireylerin serum yüksek duyarlı C-reaktif protein (hsCRP), hepsidin, kalprotektin, ferritin, demir ve doymamış demir bağlama kapasitesi (UIBC) seviyeleri belirlendi.

Bulgular: Gruplar arasında serum kalprotektin $(p<0,05)$, UIBC $(p<0,05)$, hsCRP $(p<0,05)$ ve hemoglobin $(p<0,05)$ düzeyleri açısından istatistiksel olarak anlamlı fark bulundu. Hastalar ve kontroller arasında serum hepsidin, demir ve ferritin düzeyleri açısından istatistiksel olarak anlamlı fark saptanmadı. Kalprotektin kesme değeri 212,3 (pg/mL) bulundu ve bu değer BH için duyarlılık \%100 ve özgüllük \%90 idi.

Sonuç: Serum kalprotektin, enflamatuvar durumun değerlendirilmesinde ve BH'nin tanısında faydalı biyobelirteç olabilir. Toplam demir bağlama kapasitesi ve hemoglobin, Behçet hastalarında demir eksikliği anemisini değerlendirmek için daha faydalı olabilir.

Anahtar kelimeler: Behçet hastalığı, kalprotektin, hepsidin, demir, ferritin

\section{Introduction}

Behçet's disease (BD) is an inflammatory disorder that affects the different parts of body including eyes, joints, mucocutaneous tissues, vascular and central nervous systems (1). Although genetic factors, infectious agents, heat shock proteins, endothelial cell dysfunction, oxidative stress, humoral and cellular immunity are thought to play in etiopathogenesis of BD the exact mechanism is not fully known $(1,2)$.
Previous clinical studies have emphasized the importance of neutrophil hyper activation in the pathogenesis of BD (36) Calprotectin is a cytosolic protein of polymorph nuclear leukocytes. It is released by neutrophils and monocytes during inflammation and shows proinflammatory activity (7). Calprotectin is also known as a metal-chelating antimicrobial protein of the innate immune response (8) and has a role in iron metabolism. Previous clinical studies have shown elevated serum calprotectin levels in rheumatoid arthritis (RA) and ankylosing

Address for Correspondence/Yazışma Adresi: Ahmet Karadağ Assoc. Prof., Sivas Cumhuriyet University Faculty of Medicine, Department of Physical Medicine and Rehabilitation, Sivas, Turkey

Phone: +90 5065335456 E-mail: dr_ahmetkaradag@hotmail.com ORCID ID: orcid.org/0000-0002-5284-2256 Received/Geliş Tarihi: 30.09.2020 Accepted/Kabul Tarihi: 16.03.2021

${ }^{\circ}$ Copyright 2021 by the Turkish Osteoporosis Society / Turkish Journal of Osteoporosis published by Galenos Publishing House 
spondylitis (AS) $(9,10)$. However, little is known about the change of serum calprotectin levels in BD.

Iron is an important trace element, which plays a crucial role in cytokine production, oxygen transport, cell division and the production of hemoglobin and myoglobin (11). Dysregulation of iron metabolism has been associated with defects in the immune system (12). Hepcidin is a liver-expressed protein involved in iron uptake into the circulation. Increased serum hepcidin levels have been reported in inflammatory and some rheumatic diseases (13-16).

To date, only a few clinical studies have evaluated serum calprotectin or hepcidin levels in $\mathrm{BD}$, and the majority of those studies have measured fecal calprotectin levels $(17,18)$. In addition, those studies have not adequately investigated the relationship of serum calprotectin and hepcidin levels with disease duration of BD. Therefore, the aim of this study was to measure serum calprotectin, hepcidin, iron and ferritin levels in $\mathrm{BD}$, and to investigate the relationship of serum calprotectin and hepcidin levels with disease duration. It is thought that this study provides an exciting opportunity to advance existing knowledge regarding the relationship between iron metabolism, hepcidin and calprotectin in BD patients.

\section{Materials and Methods}

This study was conducted between June 2018 and June 2019. We included $40 \mathrm{BD}$ patients who met the diagnostic criteria of the BD International Study Group (1990) and 40 healthy control subjects in the study. Subjects were excluded from the study if they were aged $<18$ or $>60$ years, had any systemic disease other than BD, such as heart, liver or kidney disease, any inflammatory rheumatic disease such as RA, AS, Familial Mediterranean fever, or systemic lupus erythematosus, any pulmonary disease, any acute or chronic infection, malignancy, metabolic, endocrine or hematological disease, were pregnant or breastfeeding, or consumed alcohol. The control group consisted of volunteers who were determined to be healthy. The control group inclusion criteria were age in the range of 18-60 years, and no known acute or chronic infection, systemic disease, or hematological or metabolic disorder. The study was approved by the Cumhuriyet University Clinical Research Ethics Committee (decision no: 2018-06/12 date: 26.06.2018). Written informed consent was obtained from each participant.

\section{Blood Sample Collection and Analyzing}

A venous blood sample was taken from each study participant into a red top tube (Becton Dickinson, UK). After clotting, the serum sample tubes were centrifuged at 3,500 rpm for 15 minutes at $4{ }^{\circ} \mathrm{C}$. The serum was aliquoted and stored at -80 ${ }^{\circ} \mathrm{C}$ until assay (WiseCryo, South Korea). The serum hepcidin and calprotectin levels were determined using the quantitative sandwich ELISA technique (Cloud-Clone Corp, Hubei, China). All assays were applied according to the manufacturer's instructions. For the measurement of serum ferritin levels, the electrochemiluminescent method was applied (Roche Cobas e601, Germany). Colorimetric methods were used to determine the serum iron and unsaturated iron binding capacity (UIBC) levels (Roche Cobas, c702, Germany). Complete blood count analysis was applied using an auto hematology analyzer (Mindray, BC 6800, China). Total iron binding capacity (TIBC) levels were calculated with the following formula; serum UIBC + serum iron.

\section{Statistical Analysis}

Data normality was evaluated using histogram, q-q graphs and D'Agostino \& Pearson normality test. Levene's test was used to assess the variance homogeneity. Student's t and MannWhitney $U$ tests were performed to compare parametric and non-parametric distributed parameters. Chi-square test was used to compare categorical variables. The correlation between quantitative data was assessed by Spearman's test. Data analysis was conducted using GraphPad Prism version 7.01 for Windows, GraphPad Software, La Jolla California USA, "www.graphpad.com" $p$ values less than $5 \%$ was considered as statistically significant. Figure 1 and 2 were obtained using BoxPlotR: a web-tool for generation of box plots (http://shiny.chemgrid.org/boxplotr/). Receiver operating characteristic (ROC) curves were plotted for the calprotectin to detect the predictive performance of the $\mathrm{BD}$ patients from healthy controls. The area under curves also, cut-offs were determined for each variable. Sensitivity, specificity, positive predictive rate, negative predictive rate and area under curve diagnostic measures were calculated. ROC analyses were conducted using Turcosa Cloud (Turcosa Ltd Co, Turkey) statistical software. A p-value less than 5\% was considered as statistically significant. In the power analysis for this study, using $\alpha=0.05 \beta=0.10(1-\beta)=0.90$, it was decided to include 40 individuals in each group, and the power of the test was $p=0.90310$.

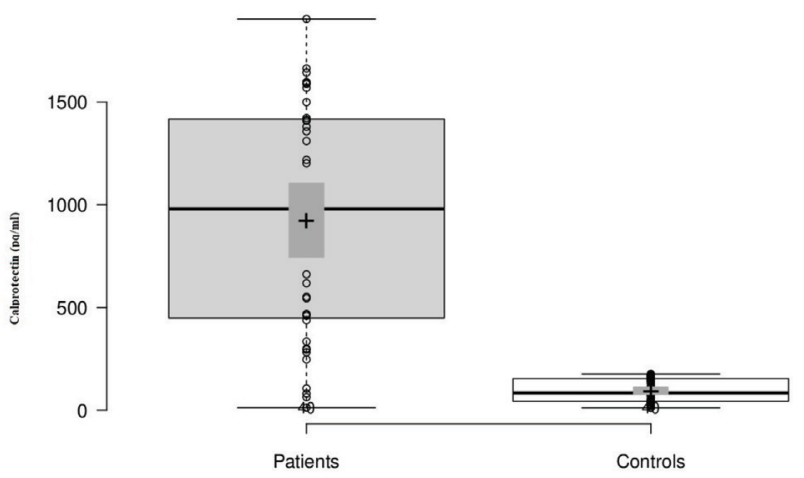

Figure 1. Comparisons of calprotectin levels between patients and controls. Center lines show the medians; box limits indicate the $25^{\text {th }}$ and $75^{\text {th }}$ percentiles as determined by $R$ software; whiskers extend 1.5 times the interquartile range from the $25^{\text {th }}$ and $75^{\text {th }}$ percentiles, outliers are represented by dots; crosses represent sample means; bars indicate $95 \%$ confidence intervals of the means. $n=40$ sample points 


\section{Results}

A statistically significant difference was not found between the groups in terms of the sociodemographic characteristics including age, gender and smoking history (Table 1). The clinical findings of the patients and control group are presented in Table 2. Median calprotectin levels were 980.80 (444.10-1420.00) and 85.12 (43.39-155.80) pg/mL in patients and controls, respectively (Figure 1). Statistically significant difference was found between the groups in respect of calprotectin $(p<0.05)$, UIBC $(p<0.05)$, high-sensitive C-reactive protein (hsCRP) $(p<0.05)$, erythrocyte sedimentation rate $(E S R)(p<0.05)$ and hemoglobin

\section{Table 1. Sociodemographic data of groups}

\begin{tabular}{|l|l|l|l|}
\hline & $\begin{array}{l}\text { Patients } \\
(\mathbf{n = 4 0 )}\end{array}$ & $\begin{array}{l}\text { Controls } \\
(\mathbf{n = 4 0 )}\end{array}$ & $\mathbf{p}$ \\
\hline Age (years) & $37.87 \pm 10.67$ & $33.42 \pm 10.29$ & 0.061 \\
\hline $\begin{array}{l}\text { Gender } \\
\text { (female/male) }\end{array}$ & $26 / 14$ & $31 / 9$ & 0.217 \\
\hline $\begin{array}{l}\text { Tobocco use } \\
\text { (no) }\end{array}$ & 34 & 38 & 0.762 \\
\hline p<0.05 value was regarded as significant & \\
\hline
\end{tabular}

\section{Table 2. Clinical findings and drug use of patients}

\begin{tabular}{|l|l|}
\hline Disease duration (month) & $82.65 \pm 45.74$ \\
\hline Oral ulcers & $40(100)$ \\
\hline Genital ulcers & $28(70)$ \\
\hline Oculer lesions & $17(42.5)$ \\
\hline Arthritis & $15(37.5)$ \\
\hline Skin lesions & $29(72.5)$ \\
\hline Pathergy & $18(45)$ \\
\hline Vascular lesions & $16(40)$ \\
\hline Drug use & - \\
\hline Colchicine & $40(100)$ \\
\hline Imuran & $4(10)$ \\
\hline TNF inhibitor & $1(2.5)$ \\
\hline $\begin{array}{l}\text { TNF: Tumor necrosis factor, results were given as mean } \pm \text { standard deviation } \\
\text { and } n \text { (\%) }\end{array}$ \\
\hline
\end{tabular}

$(p<0.05)$ levels. No statistically significant differences were not determined between the patients and the controls in terms of hepcidin, iron and ferritin levels. The laboratory findings are shown in Table 3. There was no statistically significant correlation among serum calprotectin, hepcidin and disease duration in the patients. Receiving operating characteristic analyses were applied for calprotectin and the area under the curve values were found to be 0.935 (0.87-1.00) as shown in Figure 2. Cut off values of 212.3 for calprotectin were obtained to identify the BD patients with a sensitivity and specificity of $100 \%$ and $90 \%$, respectively, in the ROC analysis (Figure 2).

\section{Discussion}

The main results of the present study were that higher calprotectin, TIBC and hsCRP levels in patients. No statistically significant difference was found between patients and controls in terms of serum hepcidin, iron ad ferritin levels. No correlations

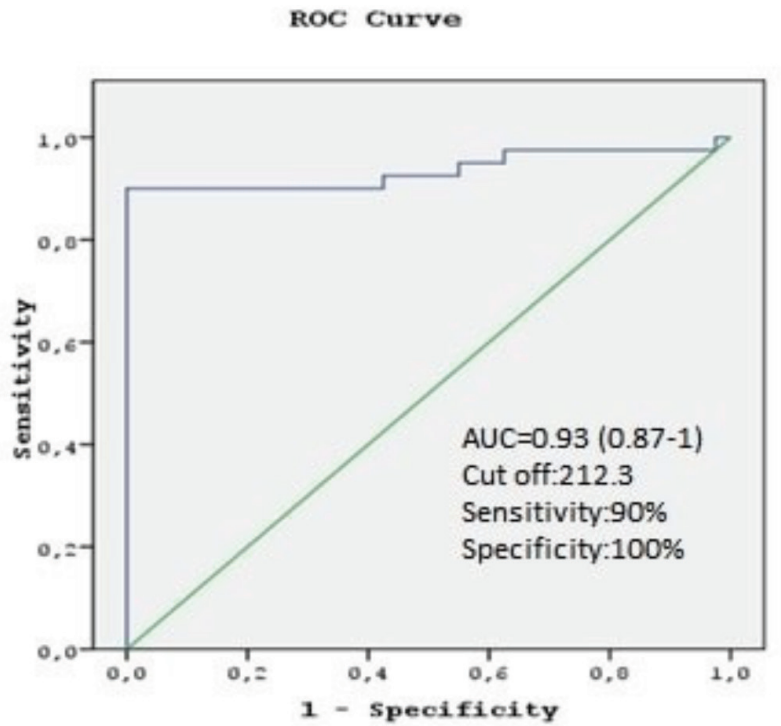

Figure 2. Evaluation of the diagnostic performance of calprotectin predicting the Behçet's patients

ROC: Receiver operating characteristic AUC: Area under the curve

\section{Table 3. Comparison of laboratory parameters between patients and controls}

\begin{tabular}{|c|c|c|c|}
\hline & Patients $(n=40)$ & Controls $(n=40)$ & $\mathbf{p}$ \\
\hline${ }^{\star}$ Calprotectin (pg/mL) & $980.80(444.10-1420.00)$ & $85.12(43.39-155.80)$ & $<0.0001$ \\
\hline Hepcidin (pg/mL) & $475.8 \pm 50.33$ & $480.5 \pm 49.08$ & 0.946 \\
\hline Hemoglobin $(\mathrm{g} / \mathrm{dL})$ & $13.16 \pm 1.55$ & $13.95 \pm 1.80$ & 0.041 \\
\hline Iron (mg/dL) & $62.85 \pm 38.37$ & $69.07 \pm 35.18$ & 0.452 \\
\hline${ }^{*}$ Ferritin $(\mu \mathrm{g} / \mathrm{L})$ & $18.98(9.36-64.52)$ & $25.37(7.80-61.56)$ & 0.785 \\
\hline $\mathrm{hsCRP}(\mathrm{mg} / \mathrm{L})$ & $6.47 \pm 5.90$ & $3.85 \pm 1.99$ & 0.011 \\
\hline UIBC (mg/dL) & $332.60 \pm 80.52$ & $240.90 \pm 103.0$ & $<0.001$ \\
\hline${ }^{*} \mathrm{ESR}(\mathrm{mm} / \mathrm{h})$ & $11.00(5.50-30.50)$ & $8.00(5.00-11.75)$ & 0.002 \\
\hline
\end{tabular}


were found among hepcidin, calprotectin and disease duration. Calprotectin is considered as an important biomarker of inflammation in various inflammatory rheumatological disorders $(7,19)$. The levels of calprotectin levels can be associated with disease activity, clinical characteristics and laboratory results in some rheumatological disorders (7). In the present study serum calprotectin levels were found higher in BD patients than healthy subjects. Serum, fecal and synovial fluid calprotectin levels have been studied in different rheumatological diseases (17-21). Fecal calprotectin levels were found to be higher in BD patients with no gastrointestinal symptoms when compared to a healthy control group (17). Omma et al. (20) reported that calprotectin levels were higher in patients with $\mathrm{BD}$ compared to healthy control subjects. It has been found higher serum calprotectin levels in $\mathrm{BD}$ patients. In the same study disease activity has been found related with serum calprotectin levels (21). A recent study showed that synovial fluid calprotectin levels might be relevant biomarker to discriminate septic arthritis from other inflammatory arthritis (19). Viemann et al. (22) reported that calprotectin induced thrombogenic and inflammatory responses in microvascular endothelial cells might play an important role in the pathogenesis of vasculit. Hirono et al. (23) reported increased serum calprotectin levels in patients with Kawasaki disease, and this may be related with disease activity. A meta-analysis reported high calprotectin levels in patients with RA (19). In a clinical study by Huang et al. (24), serum calprotectin levels were found to be higher in AS patients compared to a healthy control group. The findings of the present study are consistent with the results of previous studies. In the current study, a cut off value of $212.3 \mathrm{pg} /$ $\mathrm{mL}$ for calprotectin was obtained with sensitivity of $100 \%$ and specificity of $90 \%$ in the discrimination of the BD. In our study we also found higher hsCRP and ESR levels which are well known inflammatory markers in rheumathologic disease in patients than controls. Thus, we thought that serum calprotectin could be useful biomarker in combination with other well-known inflammatory markers to indicate the presence of inflammation in patients with BD.

Iron deficiency anemia is common clinical findings of certain rheumatic disease (25). Commonly used biomarkers to evaluate the status of iron metabolism are hepcidin, iron, ferritin and transferrin saturation (26). In this study we found lower hepcidin, ferritin and iron levels compared to healthy controls. However the differences were not statistically significant. Conflicting results have been reported on the iron metabolism biomarkers in $\mathrm{BD}$ (27-32). In a study by Kuo et al. (31) the serum iron level of BD patients was shown to be lower than that of the control group. In another study by Gonul et al. (30), the serum iron level in $\mathrm{BD}$ was found to be low, and no difference was seen in the serum ferritin level compared to healthy individuals. The serum ferritin level has been shown to be high in patients with active BD (29). It has been shown that serum hepcidin levels increase in the presence of infections and some inflammatory rheumatic diseases $(27,28)$. In a clinical study by Koca et al. (32), it was reported that serum hepcidin levels were higher in RA patients compared to the healthy control group. In contrast, Demir et al. (33), reported that serum hepcidin levels were not found to be significantly different between patients with $\mathrm{BD}$ and healthy control subjects. In another clinical study of BD by Cicek et al. (34), serum hepcidin levels in BD patients were not found to be different from those of the healthy control group. Proinflammatory cytokines increase the levels of ferritin and hepcidin levels (27). The reason for the different results in terms of hepcidin and ferritin status between our and previous studies might be related with the differences of the level of disease activities. In the current study we found higher TIBC and lower hemoglobin levels in patients than controls. TIBC and hemoglobin are the other well-known biomarkers in the diagnosis of iron deficiency anemia (35). Early detection of anemia is important to increase the quality life of patients and decrease the morbidity and mortality in rheumatic diseases (25). Thus, we thought that because of the limitations of hepcidin, ferritin and iron TIBC and hemoglobin levels may be more useful in the diagnosis and follow-up of iron deficiency anemia in Behçet patients.

The limitations of this study include the small patient population and the absence of a test to measure interleukin- 6 and fecal calprotectin.

\section{Conclusion}

Serum calprotectin may be useful biomarkers in the evaluation of inflammatory status and diagnosis of BD. To diagnosis of iron deficiency anemia in Behçet patients is important to decrease the severity of the disease. Therefore we also think that measurements of TIBC and hemoglobin may be more useful to evaluate iron deficiency anemia in Behçet patients. Further research is needed to confirm these findings and to examine possible explanations.

\section{Ethics}

Ethics Committee Approval: The study was approved by the Cumhuriyet University Clinical Research Ethics Committee (decision no: 2018-06/12 date: 26.06.2018).

Informed Consent: Written informed consent was obtained from each participant.

Peer-review: Externally peer-reviewed.

\section{Authorship Contributions}

Surgical and Medical Practices: A.K., Concept: A.K., H.O.D., Design: A.K., H.O.D., Data Collection or Processing: A.K., H.O.D., Analysis or Interpretation: A.K., H.O.D., Literature Search: A.K., H.O.D., Writing: A.K., H.O.D.

Conflict of Interest: No conflict of interest was declared by the authors.

Financial Disclosure: The authors declared that this study has received no financial support. 


\section{References}

1. Karadağ $A$, Karadağ $M$, Bora $A$, Hayta $E$, Çetin $A B$, Doğan $S C$, et al. Evaluation of hearing loss and tinnitus in Behcet's disease. Eur Arch Otorhinolaryngol 2019;276:2691-6.

2. Arica DA, Akşan B, Örem A, Altinkaynak BA, Yayli S, Sönmez M. High levels of endothelial progenitor cells and circulating endothelial cells in patients with Behçet's disease and their relationship to disease activity. An Bras Dermatol 2019;94:320-6.

3. Rustemoglu A, Erkol Inal E, Inanir A, Ekinci D, Gul U, Yigit S, et al. Clinical significance of NCOA5 gene rs2903908 polymorphism in Behçet's disease. EXCLI J 2017;16:609-17.

4. Mendoza-Pinto $C$, García-Carrasco $M$, Jiménez-Hernández $M$ Jiménez Hernández C, Riebeling-Navarro C, Nava Zavala A, et al. Etiopathogenesis of Behcet's disease. Autoimmun Rev 2010;9:241 5.

5. Perazzio SF, Soeiro-Pereira PV, Dos Santos VC, de Brito MV, Salu $B$, Oliva MLV, et al. Soluble CD40L is associated with increased oxidative burst and neutrophil extracellular trap release in Behçet's disease. Arthritis Res Ther 2017;19:235.

6. Pineton de Chambrun M, Wechsler B, Geri G, Cacoub P, Saadoun D. New insights into the pathogenesis of Behçet's disease. Autoimmun Rev 2012;11:687-98.

7. Romand X, Bernardy C, Nguyen MVC, Courtier A, Trocme C, Clapasson M, et al. Systemic calprotectin and chronic inflammatory rheumatic diseases. Joint Bone Spine 2019;86:691-8.

8. Nakashige TG, Zhang B, Krebs C, Nolan EM. Human calprotectin is an iron-sequestering host-defense protein. Nat Chem Biol 2015;11:765-71.

9. Inciarte-Mundo J, Ramirez J, Hernández MV, Ruiz-Esquide V, Cuervo A, Cabrera-Villalba SR, et al. Calprotectin and TNF trough serum levels identify power Doppler ultrasound synovitis in rheumatoid arthritis and psoriatic arthritis patients in remission or with low disease activity. Arthritis Res Ther 2016;18:160.

10. Reveille JD. Biomarkers for diagnosis, monitoring of progression and treatment responses in ankylosing spondylitis and axial spondyloarthritis. Clin Rheumatol 2015;34:1009-18.

11. Abbaspour N, Hurrell R, Kelishadi R. Review on iron and its importance for human health. J Res Med Sci 2014;19:164-74.

12. Silva B, Faustino P. An overview of molecular basis of iron metabolism regulation and the associated pathologies. Biochim Biophys Acta 2015;1852:1347-59.

13. Nemeth E, Rivera S, Gabayan V, Keller C, Taudorf S, Pedersen BK et al. IL-6 mediates hypoferremia of inflammation by inducing the synthesis of the iron regulatory hormone hepcidin. J Clin Invest 2004;113:1271-6

14. Mohammed MF, Belal D, Bakry S, Marie MA, Rashed L, Eldin RE, et al. A study of hepcidin and monocyte chemoattractant proteinin Egyptian females with systemic lupus erythematosus. J Clin Lab Anal 2014;28:306-9.

15. Østgård RD, Glerup H, Jurik AG, Kragstrup TW, Stengaard-Pedersen $\mathrm{K}$, Hetland $\mathrm{ML}$, et al. Hepcidin plasma levels are not associated with changes in haemoglobin in early rheumatoid arthritis patients. Scand J Rheumatol 2017;46:441-5.

16. Ganz T. Hepcidin-a regulator of intestinal iron absorption and iron recycling by macrophages. Best Pract Res Clin Haemato 2005; 18:171-82.

17. Özşeker B, Şahin C, Özşeker HS, Efe SC, Kav T, Bayraktar Y. The Role of Fecal Calprotectin in Evaluating Intestinal Involvement of Behçet's Disease. Dis Markers 2016;2016:5423043.

18. Kim DH, Park Y, Kim B, Kim SW, Park SJ, Hong SP, et al. Fecal calprotectin as a non-invasive biomarker for intestinal involvement of Behçet's disease. J Gastroenterol Hepatol 2017;32:595-601.
19. Baillet A, Trocmé C, Romand X, Nguyen CMV, Courtier A, Toussaint $B$, et al. Calprotectin discriminates septic arthritis from pseudogout and rheumatoid arthritis. Rheumatology (Oxford) 2019;58:164418.

20. Omma A, Sandikci SC, Colak S, Tecer D, Yucel C, Ozbalkan Z. Serum calprotectin and ischemia modified albumin levels as markers of disease activity in Behçet's disease. Postepy Dermatol Alergol 2018;35:609-613.

21. Oktayoglu P, Mete N, Caglayan M, Bozkurt M, Bozan T, Em S, et al. Elevated serum levels of calprotectin (MRP8/MRP14) in patients with Behçet's disease and its association with disease activity and quality of life. Scand J Clin Lab Invest 2015;75:106-12.

22. Viemann D, Barczyk K, Vogl T, Fischer U, Sunderkötter C, SchulzeOsthoff $\mathrm{K}$, et al. MRP8/MRP14 impairs endothelial integrity and induces a caspase-dependent and -independent cell death program. Blood 2007;109:2453-60.

23. Hirono K, Foell D, Xing $Y$, Miyagawa-Tomita S, Ye F, Ahlmann M, et al. Expression of myeloid-related protein-8 and -14 in patients with acute Kawasaki disease. J Am Coll Cardiol 2006;48:1257-64.

24. Huang J, Yin Z, Song G, Cui S, Jiang J, Zhang L. Discriminating Value of Calprotectin in Disease Activity and Progression of Nonradiographic Axial Spondyloarthritis and Ankylosing Spondylitis. Dis Markers 2017;2017:7574147.

25. Weiss G, Schett $G$. Anaemia in inflammatory rheumatic diseases. Nat Rev Rheumatol 2013;9:205-15.

26. Jankowska EA, Tkaczyszyn M, Drozd M, Ponikowski P. Monitoring of iron status in patients with heart failure. Eur Heart J Suppl 2019;21(Suppl M):M32-M5.

27. Kunireddy N, Jacob R, Khan SA, Yadagiri B, Sai Baba KSS, Rajendra Vara Prasad I, et al. Hepcidin and Ferritin: Important Mediators in Inflammation Associated Anemia in Systemic Lupus Erythematosus Patients. Indian J Clin Biochem 2018;33:406-13.

28. Swellam M, Gabal KM, Youssef SS. Interleukin-1 receptor antagonist gene polymorphism and hepcidin in rheumatoid arthritis: Correlations with clinical and laboratory indices of disease activity. IUBMB Life 2013;65:883-8.

29. Odabas AR, Karakuzu A, Cetinkaya R, Selcuk Y, Keles S, Bilen H. Increased serum ferritin levels in active Behçet's disease. Int J Clin Pract 2002;56:310-1.

30. Gonul M, Gul U, Cakmak SK, Soylu S, Kilic A. Serum iron and ferritin levels in Behçet's disease. Indian J Dermatol Venereol Leprol 2010;76:85.

31. Kuo YS, Chang JY, Wang YP, Wu YC, Wu YH, Sun A. Significantly higher frequencies of hemoglobin, iron, vitamin B12, and folic acid deficiencies and of hyperhomocysteinemia in patients with Behcet's disease. J Formos Med Assoc 2018;117:932-8.

32. Koca SS, Isik A, Ustundag B, Metin K, Aksoy K. Serum pro-hepcidin levels in rheumatoid arthritis and systemic lupus erythematosus. Inflammation 2008:31:146-53.

33. Demir B, Cicek D, Aydin S, Doğan Başkaya F. Erden I. Ucak H, et al. Relationship between metabolic syndrome and serum hepcidin level in patients with behcet's disease. Glob. Dermatology 2015:2:99-102.

34. Cicek D, Dağlı AF, Aydin S, Baskaya Dogan F, Dertlioğlu SB, Uçak $H$, et al. Does hepcidin play a role in the pathogenesis of aphthae in Behçet's disease and recurrent aphthous stomatitis? J Eur Acad Dermatol Venereol 2014;28:1500-6.

35. Killip S, Bennett JM, Chambers MD. Iron deficiency anemia. Am Fam Physician 2007;75:671-8. 